\section{COMPETITIVE INHIBITION OF SQUALENE SYNTHETASE BY SQUALESTATIN 1}

\author{
Keiji Hasumi, KiYoshi Tachikawa, \\ Kaoru Sakai, Shigeo MuraKawa, \\ Nobui Yoshikawa, ${ }^{\dagger}$ SHigenori Kumazawa ${ }^{\dagger}$ \\ and Akira ENDo \\ Department of Applied Biological Science, \\ Tokyo Noko University, \\ Fuchu, Tokyo 183, Japan \\ ${ }^{\dagger}$ Research Center, Mitsubishi Kasei Corporation, \\ Midori-ku, Yokohama 227, Japan
}

(Received for publication October 8, 1992)

Recently, 3-hydroxy-3-methylglutaryl-CoA (HMG-CoA) reductase inhibitors have received great attention as safe and effective cholesterollowering drugs ${ }^{11}$. However, cholesterol is synthesized from acetyl-CoA via a series of more than 20 enzymatic reactions. Among these, squalene synthetase, as well as HMG-CoA reductase, play key roles in the regulation of the pathway ${ }^{2,3)}$. Squalene synthetase ( $E C$ 2.5.1.21) is a microsomal enzyme which catalyzes the two sequential reactions: head-to-head condensation of farnesyl pyrophosphate (FPP) to form presqualene pyrophosphate (PSPP, Fig. 1) and reduction of PSPP to squalene, thus yielding one molecule of squalene from two molecules of FPP4).

Recently, several compounds that inhibit squalene synthetase (named squalestatins) have been isolated from Phoma sp. by DAwson et al. ${ }^{5}$. One of these metabolites, squalestatin 1 (Fig. 1), was demonstrated to be effective in lowering plasma cholesterol in marmosets ${ }^{6}$. While screening for squalene synthetase inhibitors of microbial origin we have isolated the same compound from Setosphaeria khartoumensis. This communication deals with the isolation and mechanism of action of squelestatin 1.

Setosphaeria khartoumensis L1685 was grown aerobically at $25^{\circ} \mathrm{C}$ for 14 days in a medium containing $2 \%$ corn strach, $0.5 \%$ glucose, $2.5 \%$ soybean meal, $0.5 \%$ Farmamedia (Procter \& Gamble Oilseed Products Co., U.S.A.), $0.1 \%$ Staminol (Sapporo Beer Co., Japan) and $1 \% \mathrm{CaCO}_{3}$ in flasks. Culture filtrate ( 8 liters) was mixed with $400 \mathrm{ml}$ of Diaion HP-20 and adjusted to $\mathrm{pH} 3$ with $\mathrm{HCl}$. After stirring overnight at $4^{\circ} \mathrm{C}$, the resin was packed in a column $(36 \times 390 \mathrm{~mm})$ and washed with 2 liters of $25 \mathrm{~mm}$ potassium phosphate ( $\mathrm{pH} 8.0$ ). Active compound was eluted with $400 \mathrm{ml}$ of $50 \%$ aq methanol. The active fractions were concentrated and resultant oily residue was suspended in 1 liter of water. The suspension was adjusted to $\mathrm{pH} 3$ and extracted with ethyl acetate. The organic phase was dried over $\mathrm{Na}_{2} \mathrm{SO}_{4}$ and concentrated to give $1.72 \mathrm{~g}$ of residue. After dissolving this material in $1.7 \mathrm{ml}$ of methanol, active substance $(22 \mathrm{mg})$ was isolated by a preparative HPLC (Inertsil PREP-ODS $(30 \times 250 \mathrm{~mm}$, GL Sciences Co, Japan) developed

Fig. 1. The structures of squalestatin 1 and PSPP.<smiles>C=C(CCC12OC(C(=O)O)C(O)(C(=O)O)C(C(=O)O)(O1)C(OC(=O)/C=C/C(C)CC(C)CC)C2O)C(OC(C)=O)C(C)Cc1ccccc1</smiles>

Squalestatin 1

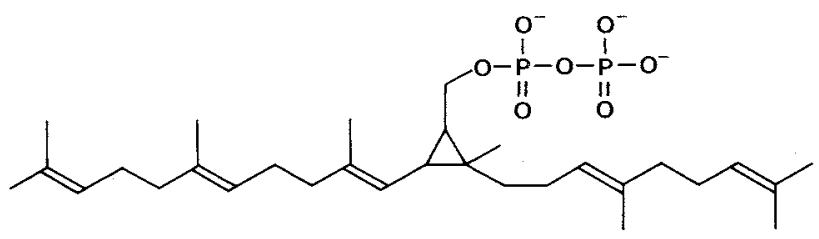

Presqualene pyrophosphate 
Fig. 2. Lineweaver-Burk plot for the inhibition of the overall squalene synthetase reaction by squalestatin 1 .

Concentrations of squalestatin 1 were $0(\bullet), 1.45$ $(0), 2.9(\Delta), 5.8(\triangle)$ and $10.1 \mathrm{nM}(\mathbf{a})$.

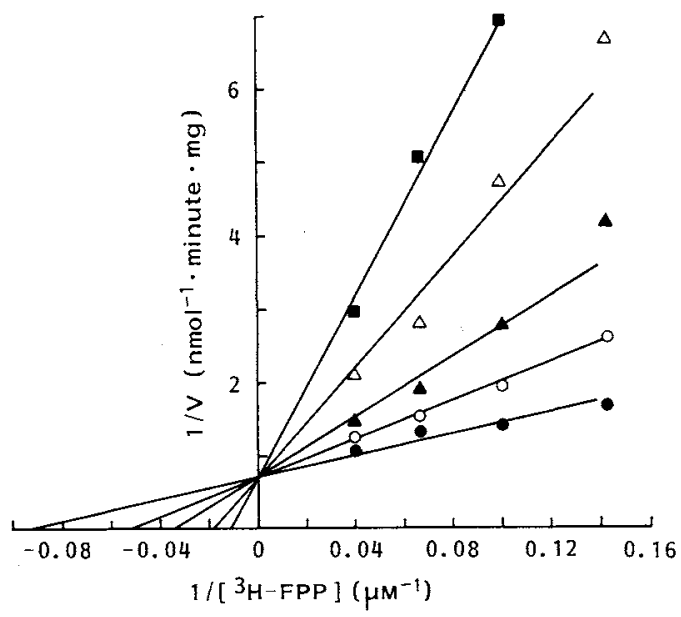

Overall squalene synthetase reaction was determined by the formation of squalene from varying concentrations of $\left[{ }^{3} \mathrm{H}\right] \mathrm{FPP}^{8}$. Reaction was started by adding $15 \mu \mathrm{g}$ of microsomal protein and continued at $37^{\circ} \mathrm{C}$ under nitrogen for 20 minutes. Each value represents the average of duplicate determinations.

Fig. 3. Inhibition of the first partial squalene synthetase reaction by squalestatin 1 .

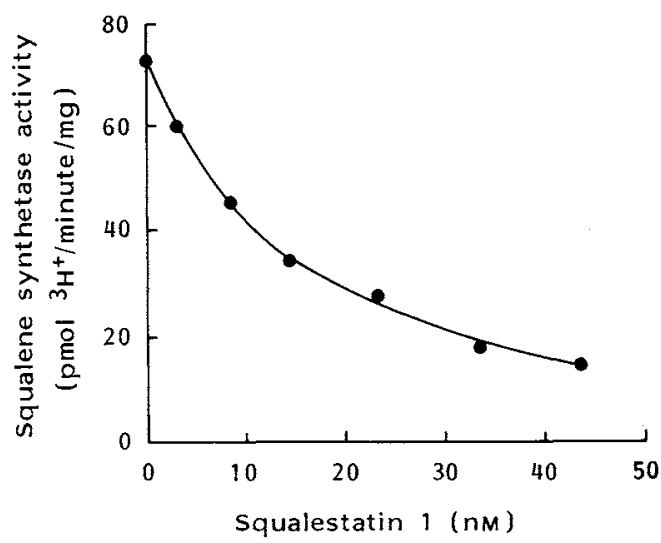

The first partial squalene synthetase reaction was determined by measuring ${ }^{3} \mathrm{H}^{+}$released in the absence of $\mathrm{NADPH}^{4)}$ using $10 \mu \mathrm{M}\left[{ }^{3} \mathrm{H}\right] \mathrm{FPP}(20 \mathrm{Ci} / \mathrm{mol})$ and $50 \mu \mathrm{g}$ of microsomal protein. Each value represents the average of duplicate determinations.

with acetonitrile $-0.1 \%$ phosphoric acid $(3: 2))$. The active compound was identified to be squalestatin 1 by a combination of chemical and spectroscopic analyses (MW 690, $\mathrm{C}_{35} \mathrm{H}_{46} \mathrm{O}_{14}$ ) (Fig. 1).
Table 1. Effects of squalestatin 1 on the conversion of $\left[{ }^{3} \mathrm{H}\right] \mathrm{FPP}$ and $\left[{ }^{3} \mathrm{H}\right] \mathrm{PSPP}$ to squalene.

\begin{tabular}{ccc}
\hline Substrate & $\begin{array}{c}\text { Squalestatin 1 } \\
(\mathrm{nM})\end{array}$ & $\begin{array}{c}\text { Squalene formed } \\
\text { (pmol/minute/mg) }\end{array}$ \\
\hline$\left[{ }^{3} \mathrm{H}\right]$ FPP & 0 & 23.4 \\
& 33.4 & 1.1 \\
{$\left[{ }^{3} \mathrm{H}\right]$ PSPP } & 0 & 11.7 \\
& 33.4 & 1.0
\end{tabular}

The second partial squalene synthetase reaction was determined using $50 \mu \mathrm{g}$ microsomal protein and $\left[{ }^{3} \mathrm{H}\right] \mathrm{PSPP}^{7)}(0.56 \mu \mathrm{M}, 30 \mathrm{Ci} / \mathrm{mol})$ as a substrate ${ }^{4)}$. Other conditions were identical to those in Fig. 2. Where indicated, $\left[{ }^{3} \mathrm{H}\right]$ FPP $(0.56 \mu \mathrm{M}, 20 \mathrm{Ci} / \mathrm{mol})$ was incubated in place of $\left[{ }^{3} \mathbf{H}\right]$ PSPP to assay overall reaction. Each value represents the average of duplicate determinations.

Squalestatin 1 inhibited squalene synthetase (overall reaction) by $50 \%$ at $3.0 \mathrm{nM}$ under the conditions employed in Fig. $2\left(10 \mu \mathrm{M}\left[{ }^{3} \mathrm{H}\right] \mathrm{FPP}\right)$. The inhibition was competitive with respect to $\left[{ }^{3} \mathrm{H}\right] \mathrm{FPP}$ with a $K i$ value of $1.6 \mathrm{~nm}$ (Fig. 2). Effects of squalestatin 1 on the two partial squalene synthetase reactions were determined. The first partial reaction, assayed by measuring ${ }^{3} \mathrm{H}^{+}$released from $\left[{ }^{3} \mathrm{H}\right] \mathrm{FPP}$ in the absence of NADPH, was inhibited $50 \%$ by squalestatin 1 at $14 \mathrm{~nm}$ (Fig. 3). The second partial reaction, determined by measuring squalene formation from $\left[{ }^{3} \mathrm{H}\right] \mathrm{PSPP}$ in the presence of NADPH, was also found to be sensitive to squalestatin 1 ; inhibition was $>90 \%$ at $33.4 \mathrm{~nm}$ (Table 1 ).

In summary, squalestatin 1 was isolated from Setosphaeria khartoumensis. Consistently with the observation by others ${ }^{6)}$, squalestatin 1 was shown to be a potent inhibitor of squalene synthetase. This inhibition was competitive with respect to the substrate FPP. Both the first and the second steps in the reaction appeared to be inhibited by squalestatin 1. As shown in Fig. 1, squalestatin 1 is structurally related to PSPP, the product of the first step, in that each compound consists of one hydrophilic moiety connected with two hydrophobic chains. Detailed mechanisms for the inhibition of these two partial reactions are to be studied further.

\section{Acknowledgments}

The authors are grateful to Dr. Kyozo OGURA for generous gift of farnesyl pyrophosphate. This work was supported in part by a Grant-in-Aid for Science Research from the Ministry of Education, Science and Culture and by a Research Grant for Cardiovascular Diseases form the Ministry of Health and Welfare, Japan 


\section{References}

1) Hunninghake, D. B.: HMG-CoA reductase inhibitors. Curr. Opin. Lipidol. 3: 22 28, 1992

2) Goldstein, J. L. \& M. S. BRown: Regulation of mevalonate pathway. Nature 343: 425 430, 1990

3) Faust, J. R.; J. L. Goldstein \& M. S. Brown: Squalene synthetase activity in human fibroblasts: regulation via the low density lipoprotein receptor. Proc. Natl. Acad. Sci. U.S.A. 76: 5018 5022, 1979

4) AGnew, W. S.: Squalene synthetase. Methods Enzymol. 110: 359 373, 1985

5) Dawson, M. J.; J. E. Farthing, P. S. Marshall, R. F. Middleton, M. J. O'Neill, A. Shuttleworth, C. Stylli, R. M. Tait, P. M. Taylor, H. G. Wildman, A. D. Buss, D. Langley \& M. V. Hayes: The squalestatins, novel inhibitors of squalene synthase produced by a species of Phoma. I. Taxonomy, fermentation, isolation, physico-chemi- cal properties and biological activity. J. Antibiotics 45: $639 \sim 647,1992$

6) Baxter, A.; B. J. Fitzgerald, J. L. Hutson, A. D. McCarthy, J. M. Motteram, B. C. Ross, M. Sapra, M. A. SnOWden, N. S. Watson, R. J. Williams \& C. WRIGHT: Squalestatin 1, a potent inhibitor of squalene synthase, which lowers serum cholesterol in vivo. J. Biol. Chem. 267: 11705 11708, 1992

7) Epstein, W. W. \& H. C. Rilling: Studies on the mechanism of squalene biosynthesis. The structure of presqualene pyrophosphate. J. Biol. Chem. 245: $4597 \sim 4605,1970$

8) Cohen, L. H.; A. M. Griffioen, R. J. A. Wanders, C. W. T. VAN RoERMUND, C. M. G. Huysmans \& H. M. G. PRINCEN: Regulation of squalene synthetase activity in rat liver: elevation by cholestyramine, but no diurnal variation. Biochem. Biophys. Res. Commun. 138: $335 \sim 341,1986$ 